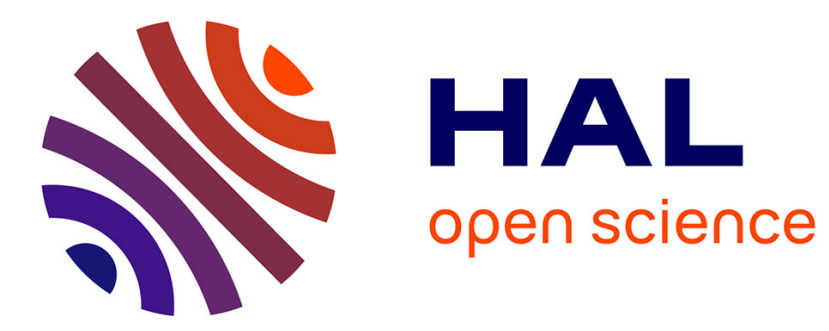

\title{
The expansion of services in European banking: implications for loan pricing and interest margins
}

Laetitia Lepetit, Emmanuelle Nys, Philippe Rous, Amine Tarazi

\section{To cite this version:}

Laetitia Lepetit, Emmanuelle Nys, Philippe Rous, Amine Tarazi. The expansion of services in European banking: implications for loan pricing and interest margins. Journal of Banking and Finance, 2008, 32 (11), pp.2325-2335. hal-01098958

\section{HAL Id: hal-01098958 \\ https://hal.science/hal-01098958}

Submitted on 30 Dec 2014

HAL is a multi-disciplinary open access archive for the deposit and dissemination of scientific research documents, whether they are published or not. The documents may come from teaching and research institutions in France or abroad, or from public or private research centers.
L'archive ouverte pluridisciplinaire $\mathbf{H A L}$, est destinée au dépôt et à la diffusion de documents scientifiques de niveau recherche, publiés ou non, émanant des établissements d'enseignement et de recherche français ou étrangers, des laboratoires publics ou privés. 


\title{
The expansion of services in European banking: implications for loan pricing and interest margins ${ }^{1}$
}

\author{
Laetitia Lepetit, Emmanuelle Nys, Philippe Rous, Amine Tarazi*
}

Université de Limoges, LAPE, 5 rue Félix Eboué, 87031 Limoges Cedex, France

June 2007

\begin{abstract}
Our study of 602 European banks over 1996-2002 investigates how the banks' expansion into fee-based services has affected their interest margins and loan pricing. We find that higher income share from commissions and fees is associated with lower margins and loan spreads. The higher the commission and fee income share, moreover, the weaker the link between bank loan spreads and loan risk. The latter result is consistent with the conjecture that banks price (or misprice) loans to increase sales of other services. That loss leader (or cross selling) hypothesis has implications for bank regulation and competition with (non-bank) lenders.
\end{abstract}

JEL classification: $\mathrm{G} 21$

Keywords: bank, interest income, non-interest income, interest margin, lending

\footnotetext{
${ }^{1}$ This paper was reviewed and accepted while Prof. Giorgio Szego was the Managing Editor of The Journal of Banking and Finance and by the past Editorial Board. We are grateful to Bob DeYoung, Donald Morgan, Paul Wachtel, Larry Wall, John Wilson, and two anonymous referees for valuable comments. We thank participants at the $12^{\text {th }}$ Global Finance Conference, the FDIC-JFRS $6^{\text {th }}$ annual Bank Research Conference, the 2007 FMA European Conference, and the $19^{\text {th }}$ Australasian Finance and Banking Conference. All remaining errors are ours *Corresponding authors: Tel: +33-555-14-92-13, emmanuelle.nys@unilim.fr (E. Nys); laetitia.lepetit@unilim.fr (L. Lepetit); philippe.rous@unilim.fr (P. Rous); amine.tarazi@unilim.fr (A. Tarazi).
} 


\section{Introduction}

With financial deregulation and the increase in disintermediation, European banks faced high competition in the 1990s. Commercial banks suffered from a sharp decline in interest margins and profitability on traditional intermediation activities. Banks reacted to this new environment by diversifying into new activities which considerably altered their income structure by reducing the importance of their traditional lines of business. For instance, for commercial banks, the share of non-interest income in total income increased from $26 \%$ to 41\% from 1989 to 1998 (ECB 2000). Banking industries in most western countries have experienced similar trends and in the case of the US the share of non-interest income has grown from $19 \%$ in the 1980 s to $43 \%$ in 2001 (Stiroh, 2004). This new environment has several implications for the safety and supervision of the banking system. First, it is not clear whether by widening the range of products they supply banks improve their risk/return trade off and their default risk. Second, the provision of a larger set of products increases the incentives for cross-subsidisation which may distort risk exposure. Consequently, among others, U.S. regulators, such as Dingell (2002), have raised questions about the pricing of loans and specifically the lending risk premium, claiming that "commercial banks may be winning high service fees by underpricing credit facilities as a loss leader to their clients".

There is an extensive literature that questions the implications of this new environment on bank risk but to our knowledge there has been no attempt to explore the link between product expansion and the pricing of traditional activities such as loans. The literature dedicated to the expansion of banks' activities beyond deposit taking and lending, either focuses on portfolio diversification effects (risk return profile) (Boyd et al., 1980; Kwan, 1998; DeYoung and Roland, 2001) or on incentives approaches (Rajan, 1991; John et al., 1994; Puri, 1996; Boyd et al., 1998). Mostly based on U.S. data, the aim of these studies is to assess the overall effect on risk and only a few papers are able to show that the combination of lending and non-interest income activities allows for diversification benefits and therefore risk reduction. Conversely, some papers find a significant positive impact of diversification on earnings volatility (DeYoung and Roland, 2001; Stiroh, 2004; Stiroh and Rumble, 2006). Another strand of the literature which analyses the optimal behaviour of bank lending and interest margin setting (Klein, 1971; Monti, 1972; Ho and Saunders 1981) has integrated risk determinants as explanatory factors (Angbazo, 1997; Wong, 1997). These studies show how factors such as credit risk and interest risk affect bank interest margins. Building on this literature, Carbó and Rodriguez (2007) have questioned the implications of the expansion of non-traditional intermediation activities on bank margins in a multi-output framework. 
Extending the Ho and Saunders model, they show that the relationship between margins and market power is dependent on the extent of output diversification. Their results also show that income from non-traditional activities impacts on net interest margins, through possible crosssubsidisation effects. However, they do not empirically analyse the link between loan pricing, risk pricing and diversification.

The aim of this paper is to revisit the bank interest margin literature to assess the impact on the lending rate of the expansion of financial intermediaries beyond traditional intermediation activities (deposit funded loans) and towards activities generating non-interest income. We use individual bank data from 1996 to 2002 for 602 European commercial and cooperative banks from 12 countries to estimate the determinants of loan rates and interest margins in a setting that accounts for the presence of non-interest activities such as commission and fee activities and trading activities. Our measure of expansion towards nontraditional activities is the net income share of non-interest income which is also split into the share of trading income and the share of commission and fee income. In order to explore whether banks engaged in product diversification actually underprice loans, we specifically focus on the determinants of loan rates.

This paper extends the earlier work on bank diversification and on bank interest margin and loan rate setting in two directions. First, this is one of the first studies dedicated to the issue of diversification that examine the case of the European banking industry which experienced tremendous changes over the last decade ${ }^{2}$. Second, this is the first paper which empirically raises the issue of loan pricing implications of the trend towards product diversification by assuming potentials for cross-selling among traditional and non-traditional activities which could induce banks to lower lending rates and underprice credit risk.

The rest of the paper is laid out as follows. Section 2 presents the specification of our econometric model of interest margins and the data we use. This section also shows how our work extends earlier studies. Section 3 presents the results of our investigation of cross-selling between lending and non-traditional activities. Section 4 concludes.

\footnotetext{
${ }^{2}$ Acharya, Hasan and Saunders (2002) have studied the case of Italian banks by looking at the degree of diversification of the loan portfolio. Their findings show that loan diversification is not guaranteed to produce a higher return and/or lower risk for banks. Another paper (Smith, Staikouras and Wood, 2003) which studies European banks focused on the correlation between non-interest income and interest income and their variability showing that the increasing importance of non-interest income stabilised profits in the banking industry during the period 1994-1998. In a more recent study based on a broad panel of European listed banks, Baele et al. (2006) find that banks with higher levels of non-interest income have higher expected returns but also higher systematic risk. Eventually, using a sample of European banks, Lepetit et al. (2007) show that the positive link between the income share of non-interest income and risk is mostly accurate for small banks and essentially driven by commission and fee activities. In their study, a higher share of trading activities is to some extent associated with lower asset and default risks for small banks.
} 


\section{Method, data and link with existing literature}

In this section we investigate the link between the pricing of loans (interest rate setting) and the shift towards non-interest activities raising the issue of potential cross-selling of loans and fee-based activities. Our aim is to examine whether banks might use some of their products, particularly their traditional lending activities as loss leaders. Banks are more likely to use loans for such a purpose because by establishing long-term relationships with their borrowers, they are able to extract surplus in the future (Petersen and Rajan, 1995). In this paper, we raise the issue of whether banks might draw benefit from non-traditional activities under such an approach.

Therefore, our hypothesis is that banks may charge lower rates on their lending activities, underpricing credit risk which may in turn increase their overall risk level. Consequently, the price banks charge for loans should be a decreasing function of non-interest income and, particularly, commission and fee income. Specifically, granting a (long term) loan increases the probability of actually selling fee generating products to a core customer while the prospects of gaining from other non-traditional activities, such as trading activities, remain unchanged. Therefore, we investigate the determinants of the lending rate by distinguishing commission and fee income and trading income. We expect loan prices to be linked with commission and fee income but not with trading income.

\subsection{Definition of variables}

We explore this issue by focusing on the determinants of the lending risk premium, i.e. the lending rate charged by the bank minus the risk free interest rate, using several definitions. Alternatively, we also consider the default spread that is the difference between the rate on a risky loan and the rate on a zero-default bond of equivalent maturity.

We use two measures as proxies for the risk premium or the default spread. W_SPREAD is the difference between the ratio of net interest income to total earning assets and either the three-month or the ten-year government bond rate. N_SPREAD is the lending rate (determined as the ratio of interest from loans to net loans) minus either the three-month or the ten-year government bond rate $^{3}$. For consistency with previous studies, we also consider the broader issue of bank interest margins with two measures of the net interest

\footnotetext{
${ }^{3}$ Our results are not affected by the choice of a given maturity for the government bond. We focus on the tenyear rate by assuming that the average maturity (duration) of loans is close to ten years. Nevertheless, we check for robustness using shorter maturities in our different estimations.
} 
margin that are frequently used in the literature (Ho and Saunders, 1981; Angbazo, 1997; Wong, 1997; Saunders and Schumacher, 2000). W_MARGIN is the ratio of net interest income (defined as interest income minus interest expense) to total earning assets. N_MARGIN is the ratio of interest from loans to net loans minus the ratio of interest expense to total liabilities (defined as total assets minus total equity).

Considering the optimal bank interest margin literature (Klein, 1971; Monti, 1972; Ho and Saunders, 1981; Angbazo, 1997; Wong, 1997; Saunders and Schumacher, 2000; Drakos, 2003; Maudos and Guevara, 2004), we first select a set of variables which are used in most studies aiming to capture the determinants of bank loan pricing.

Based on the theoretical model of Carbó and Rodriguez (2007), we also add product diversification variables as determinants of bank margins but while these authors focused on output diversification and market power in their empirical work our aim is to study the link between loan prices and the extent of income from other sources. In line with previous papers (see Stiroh (2004)), diversification of bank activities is proxied by several variables. NNII is the ratio of net non-interest income to net operating income. Net non-interest income is noninterest income less non-interest expenses; net operating income is net interest income plus net non-interest income. Our product diversification measure is also disaggregated (DeYoung and Roland, 2001; Stiroh, 2004), into commission and fee income and trading income. COM is the ratio of net commission and fee income to net operating income. TRAD is the ratio of net trading income to net operating income. Net commission income is equal to commission income minus commission expense and net trading income is equal to trading income minus trading expense. Alternatively, we also define a variable, COMSHA, which measures the proportion of net commission and fee income in net non-interest income.

\subsection{Sample}

Our sample consists of an unbalanced panel of annual report data from 1996 to 2002 for European commercial and cooperative banks in 12 countries: Austria, Belgium, Denmark, France, Italy, Netherlands, Norway, Portugal, Spain, Sweden, Switzerland, United Kingdom (see Appendix, Table A.1). The bank data are from Bankscope ${ }^{4}$. Apart from small German

\footnotetext{
${ }^{4}$ Some countries such as Greece and Germany are omitted in our sample because banks do not report information on trading revenue and on the interest they receive from loans which we need to compute the implicit lending rates. For most countries we consider in our study, Bankscope provides information on the interest received from customer loans specifically. In the case of Belgium, Switzerland and the United Kingdom we are able to consider the following items respectively: interest receivable and similar income (which excludes income from variable-yield securities), interest and discount income (which excludes interest and dividend
} 
local cooperative banks (more than 1600 banks) that we deliberately ignore, Bankscope reported at the end of 2002 balance sheets and income statements for 2129 banks for the countries we consider. We delete 1333 banks with less than three consecutive years of time series observations ${ }^{5}$. To minimize the effects of measurement errors we have excluded all the outliers (194 banks) by eliminating the extreme bank/year observations $(2.5 \%$ lowest values and $2.5 \%$ highest values) for each considered variable. We verified that the statistical properties of our clean sample of 602 banks and the initial sample of 2129 banks are similar by comparing the mean values of all our variables. Data on market interest rates come from Datastream International. Table 1 provides summary statistics.

[Insert table 1 around here]

\subsection{Model specification}

Four models are defined for each dependent variable. As a first step (equations [1] and [5] in tables 2 and 3) we estimate the margin model and the spread model referring to a general specification often used in previous papers. For spread equations, the standard deviation of the three-month interbank rate (VR3M) measures uncertainty on the money market. Therefore, a higher risk premium should be required following a rise in interest rate volatility $\left(\beta_{2}>0\right)$. When dealing with margin equations, we substitute the level of the threemonth interbank rate (R3M) for its volatility (VR3M): an increase in the level of the risk free rate implies a higher opportunity cost $\left(\alpha_{2}>0\right)$. The ratio of loan loss provisions to net loans (LLP) is considered as a measure of borrowers default risk for both margin and spread equations. A higher premium should be charged by banks to offset higher credit risk $\left(\alpha_{3}\right.$ and $\left.\beta_{3}>0\right)$. The ratio of equity to total assets (EQUITY) is introduced to account for the effect of leverage on risk levels and the required risk premium $\left(\alpha_{5} \text { and } \beta_{4}>0\right)^{6}$. The fivebank asset concentration variable (CR5) is a proxy of market structure. Higher concentration is often associated with higher lending rates. Therefore, the expected sign of the coefficient is positive $\left(\alpha_{7}\right.$ and $\left.\beta_{6}>0\right)$. Regarding personnel expenses (EXPENSES) the literature provides mixed results on the expected coefficient. Because screening and monitoring of borrowers

income on trading portfolios and financial investment) and interest received (which excludes interest received arising from debt securities and dividend income).

${ }^{5}$ All the banks in our sample publish their annual financial statements at the end of the calendar year.

${ }^{6}$ In the bank interest margin literature this variable has been introduced, under the dealership approach developed by Ho and Saunders (1981), as a proxy of the degree of bank risk aversion (McShane and Sharpe, 1985; Maudos and Guevara, 2004; Angbazo, 1997). Alternatively, in the expected utility approach of Wong (1997), the ratio of equity to total assets is considered to take into account the effect of capital regulation on margins. 
require higher personnel costs, the default risk premium charged on loans can be lower $\left(\alpha_{6}\right.$ and $\beta_{5}<0$ ). Conversely, as the cost of granting loans increases with personnel expenses banks should charge a higher premium $\left(\alpha_{6}\right.$ and $\left.\beta_{5}>0\right)$. We also consider liquidity risk for margin equations measured as the ratio of net loans to deposits (LIQUIDITY). As the ratio increases, liquidity risk increases implying a higher margin set by banks $\left(\alpha_{4}>0\right)$.

[Insert tables 2 and 3 around here]

\subsection{Hypotheses}

By augmenting several specifications of the standard model with diversification variables (see tables 2 and 3, equations [2] to [4] for margin setting and equations [6] to [8] for spread determinants) our aim is to capture loan pricing implications of the degree of bank diversification and to check for the robustness of results. In Carbó and Rodriguez (2007) product diversification affects margins either positively or negatively depending on their other determinants. We investigate this issue by looking at the link between margins (or loan prices) and our product diversification measures. As discussed above, if banks actually use loans to establish long term relationships with customers (Peterson and Rajan, 1995) enabling them to potentially increase income from non-interest activities, or use non-interest activities to attract new borrowers, we would expect a negative coefficient for the variable NNII which measures product diversification $\left(\alpha_{8}\right.$ and $\left.\beta_{7}<0\right)$ and for COMSHA, COM and TRAD which are proxies of the structure of diversification $\left(\alpha_{9}, \alpha_{10}, \alpha_{11}, \beta_{8}, \beta_{9}\right.$ and $\left.\beta_{10}<0\right)$.

Hypothesis 1: Banks more engaged in non-interest activities set a different margin and/or charge a different lending rate than less diversified banks.

Loss leader hypothesis 1': If banks use loans to attract new customers and to establish long term relationships the link between margins (or spreads) and output diversification should be negative. Banks would presumably set a lower interest margin and/or charge a lower lending rate if they expect to increase their income from non-interest activities and particularly from commission and fee activities. Alternatively, when gaining higher income from non-interest activities banks can set lower prices on loans to attract new customers.

To further investigate the issue of potential cross-selling between loans and fee-based activities we also test the extent to which credit risk affects loan interest rates. For this purpose, we estimate augmented models which capture the interaction of non-interest generating activities and default risk (see tables 4 and 5, equations [9] to [11] and equations 
[12] to [14]). Interaction variables measure the impact of non-interest generating activities on the borrower's default risk component of the lending rate and the interest margin $\left(\alpha_{12}, \alpha_{13}\right.$, $\alpha_{14}, \alpha_{15}, \beta_{11}, \beta_{12}, \beta_{13}$ and $\left.\beta_{14}<0\right)$. A negative coefficient implies that for a given level of borrower default risk, banks charge a lower default risk premium when they are more diversified ${ }^{7}$.

Hypothesis 2: Banks with more non-interest activities, particularly in commission and fee activities, underprice credit risk.

Interaction terms may not be the most accurate method to capture cross subsidy effects and specially distortion effects in credit risk pricing. Banks may actually charge a lower loan rate but collect higher fees from the same borrower to offset a higher exposure to default risk. In that case loan loss provisions based on earned interest no longer serve as a buffer against borrower default but banks can rely on other non-interest income to control their risk exposure. Nevertheless, if commission and fees are charged at an identical flat rate, that is if the same conditions apply for any customer, or if fees are not risk dependent, credit risk would be mispriced at the individual borrower level. A deeper investigation requires the use of individual borrower data to assess default risk, lending conditions and the price set for services (commission and fees) for each individual customer or for different categories of clientele.

\section{[Insert tables 4 and 5 around here]}

\section{Results and robustness checks}

\subsection{Results}

Tables 2 and 3 show the results which are obtained with two-way fixed effect panel data estimations (individual and time fixed effects). Fisher tests are used to determine if our data require the utilization of panel estimation or pooled estimation techniques. Heterogeneity across units leads us to use panel data estimations. Most panel data models are estimated under either fixed-effects or random-effects assumptions. We perform a Hausman test (Hausman, 1978) to choose between these two basic models which leads us to use a fixed

\footnotetext{
${ }^{7}$ A negative coefficient of the interaction variable implies that a more diversified bank will charge a lower risk premium than a less diversified bank but this lower risk premium need not be negative. The credit risk premium can be computed by considering the coefficient of the credit risk variable and the coefficient of the interaction variable multiplied by the bank's level of diversification. If the coefficient of the interactive variable is significantly negative the required risk premium becomes lower as diversification increases.
} 
effect model (within estimator). We deal for possible heteroskedasticity by using the White methodology when estimating the equations.

On the whole, the coefficients of the standard variables considered in the literature are significant and have the expected sign. The credit risk proxy (LLP) is significant and positive in each regression. This result is consistent with the hypothesis that banks charge higher lending rates for riskier loans.

The net non-interest income variable (NNII) introduced in equations [2] and [6] has a significant negative coefficient in all our panel data estimations suggesting possible crossselling of traditional lending activities and non-interest generating activities.

To investigate this hypothesis, we consider as a first step non-traditional income activities at a disaggregated level. We split these activities into fee-based income and trading income. Equations [4] and [8] in tables 2 and 3 show that the coefficient of COM (the income share of commission and fee income) is negative and significant. Thus, up to this stage our results are consistent with the hypothesis that banks decrease their lending rate when they are more reliant on fee income ${ }^{8}$. Conversely the coefficient of the variable indicating the extent to which bank revenue is trading based (TRAD) is not significant except when the dependent variable is the margin from all interest generating activities (W_MARGIN) comprising loans but also other market assets such as securities. Therefore, our findings do not indicate any correlation between loan prices (N_MARGIN and N_SPREAD) and the relative importance of income generated by trading activities.

As a second step, because our results suggest that banks might be cross-selling their products using loans as a loss leader and possibly underpricing credit risk, we test whether risk pricing varies with fee income share. We explore this issue by estimating the augmented models in which interaction variables are introduced to capture the presence of such a behaviour via a negative impact on the dependent variable (equations 9 to 14 in tables 4 and 5). Hence, the interaction variables stand for the mixed effect on risk pricing via the interest rate spread (risk premium) banks require on their loans. In this sense, banks may decrease their lending rate to attract or to retain borrowers which are potential customers for fee

\footnotetext{
${ }^{8}$ To further investigate the relationship between product diversification and margins (or loan prices) we perform exogeneity tests. When N_MARGIN and N_SPREAD are the dependent variables, we cannot reject $\mathrm{H}_{0}$ (no correlation between our diversification variable(s) and the error term) which suggests the absence of recursive causality between the dependent variable and the diversification variables. In other words, there is some evidence that non-interest income impacts on margins and not the reverse. When W_MARGIN and W_SPREAD are the dependent variables, our exogeneity tests reject $\mathrm{H}_{0}$. However, this result does not necessarily imply the presence of recursive causality between the diversification variables and the dependent variables. For instance, $\mathrm{H}_{0}$ could be rejected because of an omitted variable correlated with the diversification variable(s)).
} 
generating products. But their exposure to default risk may consequently become higher. In our study this effect is captured by a fall in the spread (risk premium) that is not consistent with the level of credit risk. The interaction variables are defined as the credit risk variable (LLP) multiplied by each of the non-interest income variables (NNII, COMSHA, COM and TRAD). Whereas almost all the interaction variables are significant and negative in the margin equations (when the dependent variable is W_MARGIN or N_MARGIN, table 4) only the variables involving commission and fee income are significant in the spread equations (W_SPREAD or N_SPREAD, table 5). This means that for higher levels of commission and fee shares (COM), which are always positive by construction, a higher exposure to credit risk (LLP) has a lower effect on the interest rate spread (measured by the sum of the coefficients of LLP (positive) and LLP*COM (negative) which are highly significant in table 5) ${ }^{9}$. Hence, according to our results the non-interest income subsidy effect distorts credit risk pricing for banks expanding commission and fee activities but the development of trading activities does not significantly affect the link between credit risk and the pricing of loans. As discussed above (section 2.4), our results are based on the assumption that banks do not charge higher fees to borrowers with higher default risk. A deeper insight on this issue requires detailed data on individual borrower's default risk, lending conditions and fees paid for banking services.

\subsection{Robustness checks and further issues ${ }^{10}$}

Several robustness checks are performed. First, we deal with possible trend issues (decrease in interest margins due to higher competition and higher proportion of non-interest generating activities at the end of the sample period) by running cross-section estimations for each year instead of introducing time fixed effects. Second, we run our estimations by introducing a time trend instead of a fixed time effect in our panel data models and for further checks by first differencing the variables. Overall, the main conclusions remain valid.

We also perform a number of robustness checks that are specification related. First, we include country dummies to capture the presence of country specific effects. Second, to

\footnotetext{
${ }^{9}$ To assess the overall effect of credit risk on the dependent variable, one needs to consider not only the coefficient of LLP but also the coefficients of the interaction variables (LLP $\times$ NNII, LLP $\times$ COMSHA, LLP $\times$ COM or LLP $\times$ TRAD). More precisely, if we consider equation $12^{\prime}$ in Table 5 , the impact of credit risk on the dependent variable for a given bank which exhibits, for a given year, a value of NNII equal to $40 \%$, is equal to the coefficient of LLP + (the coefficient of $($ LLP $\times$ NNII $) \times$ the value of NNII taken by the bank): $0.636+(-0.644$ $\times 0.4)$ that is a value equal to 0.378 . In this case credit risk is not fully taken into account in the loan rate setting process (a coefficient of 0.378 instead of a coefficient of 0.636 without the cross-selling effect).

${ }^{10}$ The results from the estimations conducted in this section are available from the authors on request.
} 
control for macroeconomic conditions, we introduce each country's growth of GDP in our estimations. Third, when calculating the spread, we use the three-month interbank rate (instead of the ten-year government bond rate). Fourth, we run the regressions by using two other proxies of market structure, the three-bank asset concentration and the Herfindhal index (instead of the five-bank asset concentration). Fifth, we introduce in our estimations the ratio of total operating expense to operating income as an alternative to the ratio of personnel expenses to total assets. Sixth, other control variables such as the ratio of loans to total assets and the ratio of deposits to total assets are also included in the regressions. Our conclusions regarding the inclusion of product diversification variables remain unchanged.

To check for sample representativeness, we estimate all the equations using a larger sample which is not restricted to three consecutive years of available information for each bank (6535 observations instead of 4048 for W_MARGIN and W_SPREAD, 3859 observations instead of 2342 for N_MARGIN and N_SPREAD). To examine the accuracy of our results, regressions for W_MARGIN and W_SPREAD are also carried out on a sample constrained by the availability of the data to compute N_MARGIN and N_SPREAD with an identical number of observations (2342) for all the equations. Our conclusions are unaltered.

Eventually, to further examine issues related to size and diversification we carry out a deeper investigation of our sample.

Our sample comprises large and small banks with different types of operations and clienteles and therefore our results need to be further checked by considering size effects. Because they might be serving larger borrowers with lower default risk large banks exhibit, in our sample, a lower lending rate on average. Again, in our sample, large banks are also slightly more diversified (higher share of non-interest income) than small banks. Moreover, non-interest income stems from various activities which are more innovation driven for large banking corporations but to a large extent linked to traditional activities for small local banks. We therefore conduct the estimations separately for large banks (total assets $>1$ billion Euros) and small banks (total assets $<1$ billion Euros). Our results show that small and large banks do not behave differently and that our findings are not biased by the fact that larger banks which exhibit lower lending rates are on average more diversified than small banks.

We also check whether the level of diversification might possibly influence bank's strategies and therefore our results. At this end, we differentiate banks with relatively high and relatively low shares of commission and fee income (ratio of net commission income to net operating income, COM, higher than the third quartile $\mathrm{Q}_{75}$ and COM lower than the first 
quartile $\mathrm{Q}_{25}$ ). We then run the estimations separately for the two sub-samples of banks based on this criterion. Results are mainly the same for the two types of banks.

In addition, we also consider as a sub-sample banks for which loan activities represent a significant share of their balance sheet (i.e. at least twenty percent of banks' total assets). Under this restriction it is assumed that to engage in cross-selling banks must have first developed loan activities to a certain extent. All conclusions concerning the variables of interest remain unchanged.

\section{Conclusion}

The objective of this study was to analyze the implications of the trend towards stronger product diversification in the European banking industry. In addition to risk related issues addressed in previous papers we test for a possible cross-selling behaviour of interest and non-interest products by analysing the determinants of the risk premium charged by banks on their loans. Specifically, we find that higher reliance on fee-based activities is associated with lower lending rates and that borrower default risk is underpriced in the lending rates charged by banks with higher fee-income shares. Therefore, our findings suggest that banks may use loans as a loss leader raising the issue of how cross-selling strategies should be addressed by regulators to control for bank risk. In this sense our results may explain the positive relationship between risk and bank product diversification found in some studies (DeYoung and Roland, 2001; Stiroh, 2004; Stiroh and Rumble, 2006; Baele et al. 2006; Lepetit et al. 2007). Conversely, we do not find a link between lending rates and the growing share of trading activities in bank income statements.

Our conclusions are based on the assumption that banks do not charge higher fees when lending to riskier borrowers and that on average higher income from commission and fee activities does not serve as a buffer against default risk along with traditional instruments such as loan loss provisions. A deeper investigation on this issue requires access to more detailed data on the default risk and lending conditions of individual borrowers but also on individual prices for banking services. Nevertheless, our findings suggest that, for more diversified banks, there is a weaker link between provisions for expected loan losses (as measured by loan loss provisions) and expected loan losses. 
Table 1. Descriptive statistics for European commercial and cooperative banks (average over 1996-2002)

\begin{tabular}{|c|c|c|c|c|c|c|c|c|c|c|c|c|c|c|c|c|}
\hline & LOANS & DEP & EQUITY & LLP & EXPENSES & $\mathrm{ROA}$ & ROE & W_MARGIN & N_MARGIN & W_SPREAD & N_SPREAD & $\mathrm{NII}$ & NNII & $\mathrm{COM}$ & TRAD & TA \\
\hline Mean & 60.64 & 52.18 & 8.77 & 0.67 & 1.62 & 0.79 & 9.30 & 2.79 & 0.93 & 1.40 & 1.40 & 65.51 & 34.48 & 27.00 & 6.03 & 18546 \\
\hline Max & 95.93 & 91.89 & 53.42 & 9.28 & 21.48 & 16.08 & 68.99 & 10.42 & 18.18 & 16.16 & 25.83 & 100 & 99.96 & 96.77 & 78.35 & 745000 \\
\hline Min & 5.69 & 0.75 & 0.42 & -2.02 & 0.07 & -14.87 & -175.77 & 0 & -23.42 & -4.15 & -5.35 & 0.03 & 0 & -18.31 & -70.80 & 17 \\
\hline Std & 17.45 & 16.06 & 5.82 & 0.72 & 1.11 & 1.00 & 10.13 & 1.20 & 4.58 & 1.72 & 3.06 & 18.94 & 18.94 & 15.77 & 8.69 & 69238 \\
\hline
\end{tabular}

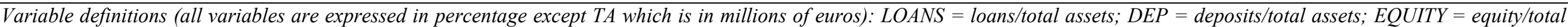

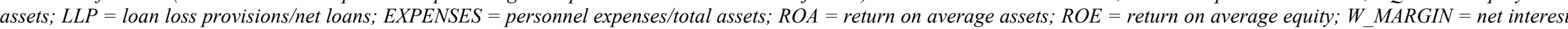

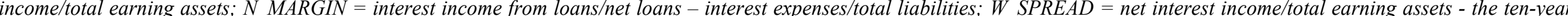

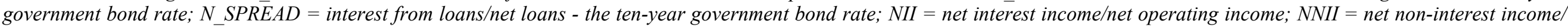
net operating income; $C O M=$ net commission income/net operating income; TRAD = net trading income/net operating income; TA : total assets in millions of euros. 
Table 2. Two way fixed effect regression (LSDV): impact of product diversification on net interest margin for European banks (1996-2002)

MARGIN $_{\mathrm{it}}=\alpha_{1 \mathrm{i}}+\alpha_{2} \mathrm{R} \mathrm{M}_{\mathrm{j}(\mathrm{i}) \mathrm{t}}+\alpha_{3}$ LLP $_{\mathrm{it}}+\alpha_{4}$ LIQUIDITY $_{\mathrm{it}}+\alpha_{5}$ EQUITY $_{\mathrm{it}}+\alpha_{6}$ EXPENSES $_{\mathrm{it}}+\alpha_{7} \mathrm{CR}_{\mathrm{j}(\mathrm{i}) \mathrm{t}}+\varepsilon_{\mathrm{it}}$

[1] or [1']

MARGIN $_{\mathrm{it}}=\alpha_{1 \mathrm{i}}+\alpha_{2}$ R3M $_{\mathrm{j}(\mathrm{i}) \mathrm{t}}+\alpha_{3}$ LLP $_{\mathrm{it}}+\alpha_{4}$ LIQUIDITY $_{\mathrm{it}}+\alpha_{5}$ EQUITY $_{\mathrm{it}}+\alpha_{6}$ EXPENSES $_{\mathrm{it}}+\alpha_{7} \mathrm{CR}_{\mathrm{j}(\mathrm{i}) \mathrm{t}}+\alpha_{8} \mathrm{NNII}_{\mathrm{it}}+\varepsilon_{\mathrm{it}}$

[2] or [2']

MARGIN $_{\mathrm{it}}=\alpha_{1 \mathrm{i}}+\alpha_{2} \mathrm{R} \mathrm{M}_{\mathrm{j}(\mathrm{i}) \mathrm{t}}+\alpha_{3}$ LLP $_{\mathrm{it}}+\alpha_{4}$ LIQUIDITY $_{\mathrm{it}}+\alpha_{5}$ EQUITY $_{\mathrm{it}}+\alpha_{6}$ EXPENSES $_{\mathrm{it}}+\alpha_{7} \mathrm{CR}_{\mathrm{j}(\mathrm{i}) \mathrm{t}}+\alpha_{8} \mathrm{NNII}_{\mathrm{it}}+\alpha_{9} \mathrm{COMSHA}_{\mathrm{it}}+\varepsilon_{\mathrm{it}}$

[3] or [3']

MARGIN $_{\mathrm{it}}=\alpha_{1 \mathrm{i}}+\alpha_{2} \mathrm{R} \mathrm{M}_{\mathrm{j}(\mathrm{i}) \mathrm{t}}+\alpha_{3} \operatorname{LLP}_{\mathrm{it}}+\alpha_{4}$ LIQUIDITY $_{\mathrm{it}}+\alpha_{5}$ EQUITY $_{\mathrm{it}}+\alpha_{6}$ EXPENSES $_{\mathrm{it}}+\alpha_{7} \mathrm{CR}_{\mathrm{j}(\mathrm{i}) \mathrm{t}}+\alpha_{10} \mathrm{COM}_{\mathrm{it}}+\alpha_{11}$ TRAD $_{\mathrm{it}}+\varepsilon_{\mathrm{it}}$

$[4]$ or [4']

\begin{tabular}{|c|c|c|c|c|c|c|c|c|c|c|c|}
\hline Equation & $\begin{array}{c}\text { R3M } \\
(+)\end{array}$ & $\begin{array}{c}\text { LLP } \\
(+)\end{array}$ & $\begin{array}{c}\text { LIQUIDITY } \\
(+)\end{array}$ & $\begin{array}{c}\text { EQUITY } \\
(+)\end{array}$ & $\begin{array}{c}\text { EXPENSES } \\
(+/-)\end{array}$ & $\begin{array}{c}\text { CR5 } \\
(+)\end{array}$ & $\begin{array}{c}\text { NNII } \\
(-)\end{array}$ & $\begin{array}{c}\text { COMSHA } \\
(-)\end{array}$ & $\begin{array}{c}\mathrm{COM} \\
(-)\end{array}$ & $\begin{array}{c}\text { TRAD } \\
(-)\end{array}$ & $\mathrm{R}^{2}$ \\
\hline \multicolumn{12}{|c|}{ Dependent variable: $W$ MARGIN (4048 obs.) } \\
\hline [1] & $\begin{array}{c}0.140^{* * *} \\
(5.814)\end{array}$ & $\begin{array}{c}0.004^{* *} \\
(2.343)\end{array}$ & $\begin{array}{c}0.004 \\
(1.537)\end{array}$ & $\begin{array}{c}0.048^{* * *} \\
(4.432)\end{array}$ & $\begin{array}{c}0.332^{* * *} \\
(8.218)\end{array}$ & $\begin{array}{l}0.010^{*} \\
(1.898)\end{array}$ & - & - & - & - & 0.94 \\
\hline$[2]$ & $\begin{array}{c}0.139 * * * \\
(6.118)\end{array}$ & $\begin{array}{c}0.002^{* * * *} \\
(3.178)\end{array}$ & $\begin{array}{c}0.004 * * \\
(2.207)\end{array}$ & $\begin{array}{c}0.041 * * * \\
(3.887)\end{array}$ & $\begin{array}{c}0.364 * * * \\
(8.866)\end{array}$ & $\begin{array}{c}0.013 * * \\
(2.260)\end{array}$ & $\begin{array}{c}-0.013 * * * \\
(-4.670)\end{array}$ & - & - & - & 0.94 \\
\hline$[3]$ & $\begin{array}{c}0.141 * * * \\
(6.203)\end{array}$ & $\begin{array}{c}0.003 * * \\
(2.219)\end{array}$ & $\begin{array}{c}0.003 * * \\
(1.994)\end{array}$ & $\begin{array}{c}0.042 * * * \\
(4.118)\end{array}$ & $\begin{array}{c}0.368 * * * \\
(9.001)\end{array}$ & $\begin{array}{c}0.013 * * \\
(2.303)\end{array}$ & $\begin{array}{c}-0.013 * * * \\
(-4.536)\end{array}$ & $\begin{array}{c}-0.002 \\
(-0.282)\end{array}$ & - & - & 0.94 \\
\hline$[4]$ & $\begin{array}{c}0.119 * * * \\
(4.369)\end{array}$ & $\begin{array}{l}0.004 * * \\
(2.224)\end{array}$ & $\begin{array}{l}0.003^{*} \\
(1.667)\end{array}$ & $\begin{array}{c}0.039 * * * \\
(3.907)\end{array}$ & $\begin{array}{c}0.385 * * * \\
(9.227)\end{array}$ & $\begin{array}{c}0.013 * * \\
(2.255)\end{array}$ & - & - & $\begin{array}{c}-0.022 * * * \\
(-5.668)\end{array}$ & $\begin{array}{c}-0.018 * * * \\
(-8.581)\end{array}$ & 0.95 \\
\hline \multicolumn{12}{|c|}{ Dependent variable: $N$ MARGIN (2342 obs.) } \\
\hline$\left[1^{\prime}\right]$ & $\begin{array}{c}0.248^{* * *} \\
(2.813)\end{array}$ & $\begin{array}{c}0.005 * * \\
(2.046)\end{array}$ & $\begin{array}{c}-0.055^{* * *} \\
(-8.130)\end{array}$ & $\begin{array}{l}-0.108^{*} \\
(-1.861)\end{array}$ & $\begin{array}{c}0.280 \\
(0.958)\end{array}$ & $\begin{array}{c}0.015 \\
(0.555)\end{array}$ & - & - & - & - & 0.91 \\
\hline [2’] & $\begin{array}{c}0.249 * * * \\
(2.804)\end{array}$ & $\begin{array}{l}0.021 * * \\
(2.210)\end{array}$ & $\begin{array}{c}-0.054 * * * \\
(-7.820)\end{array}$ & $\begin{array}{l}-0.111^{*} \\
(-1.783)\end{array}$ & $\begin{array}{c}0.299 \\
(0.997)\end{array}$ & $\begin{array}{c}0.015 \\
(0.619)\end{array}$ & $\begin{array}{c}-0.005 * * * \\
(-2.531)\end{array}$ & - & - & - & 0.91 \\
\hline [3'] & $\begin{array}{c}0.249 * * * \\
(2.801)\end{array}$ & $\begin{array}{l}0.020^{* *} \\
(2.198)\end{array}$ & $\begin{array}{c}-0.054 * * * \\
(-7.774)\end{array}$ & $\begin{array}{l}-0.111^{*} \\
(-1.786)\end{array}$ & $\begin{array}{c}0.298 \\
(0.995)\end{array}$ & $\begin{array}{l}0.015 \\
(0.607)\end{array}$ & $\begin{array}{c}-0.005 * * * \\
(-2.563)\end{array}$ & $\begin{array}{c}-0.016 \\
(-0.876)\end{array}$ & & & 0.91 \\
\hline [4'] & $\begin{array}{c}0.254 * * * \\
(2.747)\end{array}$ & $\begin{array}{c}0.007 * * * \\
(3.065)\end{array}$ & $\begin{array}{c}-0.055^{* * *} \\
(-8.004)\end{array}$ & $\begin{array}{l}-0.111^{*} \\
(-1.898)\end{array}$ & $\begin{array}{c}0.295 \\
(0.973)\end{array}$ & $\begin{array}{c}0.017 \\
(0.652)\end{array}$ & - & - & $\begin{array}{c}-0.003 * * * \\
(-2.253)\end{array}$ & $\begin{array}{c}-0.012 \\
(-1.060)\end{array}$ & 0.91 \\
\hline
\end{tabular}

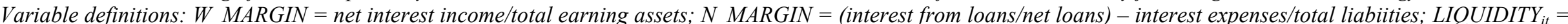
net loans/deposits; $C R \overline{5}_{j t}=$ five-bank asset concentration for country $j ; R 3 M_{j t}=$ the three-month interbank rate for country $j ;$ LLP $P_{i t}=$ loan loss provisions $/$ net loans for bank $i$

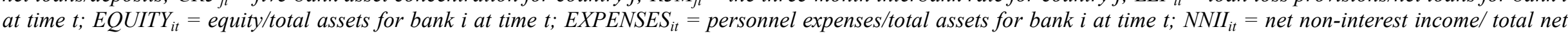
operating income for bank $i$ at time $t ; C_{i t}=$ net commission and fee incomel total net operating income for bank $i$ at time $t ;$ TRAD operating income for bank $i$ at time $t$; $C O M S H A_{i t}=$ net commission and fee income/ net non-interest income. 
Table 3. Two way fixed effect regression (LSDV): impact of product diversification on risk premium for European banks (1996-2002)

\begin{tabular}{|c|c|c|c|c|c|c|c|c|c|c|}
\hline & & & & & & & & & or $[5$, & \\
\hline $\begin{array}{l}\text { SPREAD } \\
\text { SPREAD }=\end{array}$ & $\begin{array}{l}+\beta_{2} \text { VR3M } \\
+\beta_{2} \text { VR3M }\end{array}$ & $\begin{array}{l}-\beta_{3} \operatorname{LLP}_{\mathrm{it}}+ \\
-\beta_{3} \mathrm{LLP}_{\mathrm{it}}+\end{array}$ & QUUITY ${ }_{i t}+\beta$ & $\begin{array}{l}\text { XENSES }_{\mathrm{it}}+\beta_{\mathrm{f}} \\
\text { XPENSES }_{\mathrm{it}}+\beta_{\mathrm{f}}\end{array}$ & $\begin{array}{l}5_{\mathrm{jt}}+\varepsilon_{\mathrm{it}} \\
5_{\mathrm{it}}+\beta_{7} \mathrm{NN}\end{array}$ & & & & $\begin{array}{l}\text { or }[3] \\
\left.\text { or [ } 6^{\prime}\right]\end{array}$ & \\
\hline SPREAD $_{\mathrm{it}}=$ & $+\beta_{2}$ VR3M & $-\beta_{3} \operatorname{LLP}_{\mathrm{it}}+$ & QUITY $_{\mathrm{it}}+\beta$ & XPENSES $_{\mathrm{it}}+\beta_{6}$ & $5_{\mathrm{jt}}+\beta_{7} \mathrm{NNII}$ & $3_{8} \mathrm{COMSHA}_{\mathrm{it}}$ & & & or [ ['] & \\
\hline SPREAD $_{\mathrm{it}}=$ & $+\beta_{2}$ VR3M & $-\beta_{3} \operatorname{LLP}_{\mathrm{it}}+$ & QUITY $_{\mathrm{it}}+$ & XPENSES $_{\mathrm{it}}+\beta_{\mathrm{c}}$ & $5_{\mathrm{jt}}+\beta_{9} \mathrm{CON}$ & $\beta_{10}$ TRAD $_{\text {it }}+$ & & & or [ [8'] & \\
\hline Equation & $\begin{array}{c}\text { VR3M } \\
(+)\end{array}$ & $\begin{array}{c}\text { LLP } \\
(+)\end{array}$ & $\begin{array}{c}\text { EQUITY } \\
(+)\end{array}$ & $\begin{array}{c}\text { EXPENSES } \\
(+/-)\end{array}$ & $\begin{array}{c}\text { CR5 } \\
(+)\end{array}$ & $\begin{array}{c}\text { NNII } \\
(-)\end{array}$ & $\begin{array}{c}\text { COMSHA } \\
(-)\end{array}$ & $\begin{array}{c}\mathrm{COM} \\
(-)\end{array}$ & $\begin{array}{c}\text { TRAD } \\
(-)\end{array}$ & R2 \\
\hline & Dependent & riable: $W$ & $E A D$ & & & & & & & \\
\hline [5] & $\begin{array}{c}0.549^{* * *} \\
(4.141)\end{array}$ & $\begin{array}{c}0.426^{* * *} \\
(5.821)\end{array}$ & $\begin{array}{l}-0.018^{*} \\
(-1.675)\end{array}$ & $\begin{array}{l}0.125^{* *} \\
(2.017)\end{array}$ & $\begin{array}{c}-0.002 \\
(-0.716)\end{array}$ & - & - & - & - & 0.51 \\
\hline [6] & $\begin{array}{c}0.343^{* *} \\
(2.611)\end{array}$ & $\begin{array}{c}0.443 * * * \\
(6.315)\end{array}$ & $\begin{array}{r}-0.025^{* *} \\
(-2.383)\end{array}$ & $\begin{array}{c}0.347^{* * *} \\
(5.175)\end{array}$ & $\begin{array}{c}0.004 \\
(1.531)\end{array}$ & $\begin{array}{c}-0.021 * * * \\
(-8.317)\end{array}$ & - & - & - & 0.51 \\
\hline [7] & $\begin{array}{c}0.340^{* *} \\
(2.582)\end{array}$ & $\begin{array}{c}0.442 * * * \\
(6.315)\end{array}$ & $\begin{array}{r}-0.025 * * \\
(-2.363)\end{array}$ & $\begin{array}{c}0.350 * * * \\
(5.211)\end{array}$ & $\begin{array}{l}0.004^{*} \\
(1.672)\end{array}$ & $\begin{array}{c}-0.022 * * * \\
(-8.301)\end{array}$ & $\begin{array}{c}-0.083 \\
(-1.061)\end{array}$ & - & - & 0.51 \\
\hline [8] & $\begin{array}{l}0.257^{*} \\
(1.865)\end{array}$ & $\begin{array}{c}0.440^{* * *} * \\
(6.350)\end{array}$ & $\begin{array}{c}-0.014 \\
(-1.217)\end{array}$ & $\begin{array}{c}0.317 * * * \\
(2.846)\end{array}$ & $\begin{array}{c}0.003 \\
(1.330)\end{array}$ & - & - & $\begin{array}{c}-0.034 * * * \\
(-9.149)\end{array}$ & $\begin{array}{c}0.002 \\
(0.635)\end{array}$ & 0.51 \\
\hline & Dependent & riable: $N \_S$ & $E A D(2342$ & & & & & & & \\
\hline$\left[5^{\prime}\right]$ & $\begin{array}{c}1.379^{* * *} \\
(6.995)\end{array}$ & $\begin{array}{c}0.730^{* * * *} \\
(7.383)\end{array}$ & $\begin{array}{c}0.090^{* * * *} \\
(9.005)\end{array}$ & $\begin{array}{l}0.207^{* * *} \\
(2.515)\end{array}$ & $\begin{array}{c}0.054^{* * *} \\
(15.333)\end{array}$ & - & - & - & - & 0.20 \\
\hline [6'] & $\begin{array}{c}1.391 * * * \\
(6.967)\end{array}$ & $\begin{array}{c}0.732 * * * \\
(7.228)\end{array}$ & $\begin{array}{c}0.088^{* * * *} \\
(8.700)\end{array}$ & $\begin{array}{c}0.204^{* *} \\
(2.128)\end{array}$ & $\begin{array}{c}0.053^{* * * *} \\
(16.324)\end{array}$ & $\begin{array}{c}-0.004 * * * \\
(-2.957)\end{array}$ & - & - & - & 0.21 \\
\hline [7'] & $\begin{array}{c}1.397^{* * *} \\
(7.000)\end{array}$ & $\begin{array}{c}0.723 * * * \\
(7.154)\end{array}$ & $\begin{array}{c}0.087^{* * * *} \\
(8.626)\end{array}$ & $\begin{array}{c}0.209^{* *} \\
(2.164)\end{array}$ & $\begin{array}{c}0.054^{* * * *} \\
(16.394)\end{array}$ & $\begin{array}{c}-0.005^{* * * *} \\
(-2.966)\end{array}$ & $\begin{array}{c}-0.166^{* * *} \\
(-3.010)\end{array}$ & - & - & 0.21 \\
\hline [8'] & $\begin{array}{c}1.344^{* * *} \\
(6.542)\end{array}$ & $\begin{array}{c}0.727 * * * \\
(6.889)\end{array}$ & $\begin{array}{c}0.093 * * * \\
(8.668)\end{array}$ & $\begin{array}{l}0.175^{*} \\
(1.888)\end{array}$ & $\begin{array}{l}0.054 * * * \\
(15.940)\end{array}$ & - & - & $\begin{array}{r}-0.001 * * \\
(-2.205)\end{array}$ & $\begin{array}{c}0.030 \\
(0.528)\end{array}$ & 0.21 \\
\hline
\end{tabular}

Variable definitions: $W$ SPREAD = the ratio of net interest income to total earning assets - the ten-year government bond rate; $N$ SPREAD = lending rate determined as the

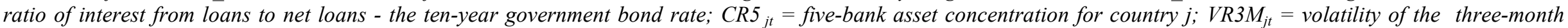
interbank rate (standard deviation computed with daily data) for country $j ; L L P_{i t}=$ loan loss provisions/net loans for bank $i$ at time $t ; E Q U I T Y_{i t}=e^{2}$ equity/total assets for bank

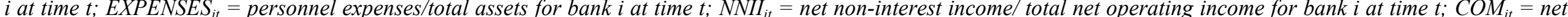
commission and fee incomel total net operating income for bank $i$ at time $t ; T_{R A D}$ it $=$ net trading income/ total net operating income for bank $i$ at time $t$; $C O M S H A_{i t}=$ net commission and fee income/ net non-interest income. 
Table 4. Two way fixed effect regression (LSDV): impact of interaction variables (product diversification*credit risk) on net interest margin for European banks (1996-2002)

MARGIN $_{\mathrm{it}}=\alpha_{1 \mathrm{i}}+\alpha_{2} \mathrm{R} \mathrm{M}_{\mathrm{j}(\mathrm{i}) \mathrm{t}}+\alpha_{3}$ LLP $_{\mathrm{it}}+\alpha_{4}$ LIQUIDITY $_{\mathrm{it}}+\alpha_{5}$ EQUITY $_{\mathrm{it}}+\alpha_{6}$ EXPENSES $_{\mathrm{it}}+\alpha_{7}$ CR $_{\mathrm{j}(\mathrm{i}) \mathrm{t}}+\alpha_{12}\left(\operatorname{LLP}_{\mathrm{it}} \times\right.$ NNII $\left._{\mathrm{it}}\right) / 100+\varepsilon_{\mathrm{it}}$

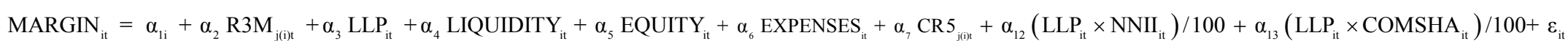

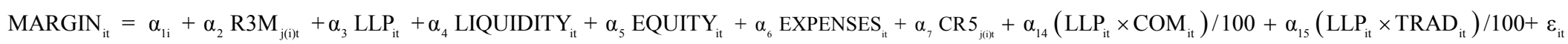

\begin{tabular}{|c|c|c|c|c|c|c|c|c|c|c|c|}
\hline & $\begin{array}{c}\text { R3M } \\
(+)\end{array}$ & $\begin{array}{l}\text { LLP } \\
(+)\end{array}$ & $\begin{array}{l}\text { LIQUIDITY } \\
(+)\end{array}$ & $\begin{array}{l}\text { EQUITY } \\
(+)\end{array}$ & $\begin{array}{c}\text { EXPENSES } \\
(+/-)\end{array}$ & $\begin{array}{c}\text { CR5 } \\
(+)\end{array}$ & $\begin{array}{c}\text { LLP* NNII } \\
/ 100 \\
(-)\end{array}$ & $\begin{array}{c}\text { LLP*COMSHA } \\
/ 100 \\
(-)\end{array}$ & $\begin{array}{c}\text { LLP*COM } \\
/ 100 \\
(-)\end{array}$ & $\begin{array}{c}\text { LLP*TRAD } \\
/ 100 \\
(-)\end{array}$ & $\mathrm{R}^{2}$ \\
\hline \multicolumn{12}{|c|}{ Dependent variable: $W$ MARGIN (4048 obs.) } \\
\hline [9] & $\begin{array}{c}0.129^{* * *} \\
(4.999)\end{array}$ & $\begin{array}{c}0.116^{* * *} \\
(2.758)\end{array}$ & $\begin{array}{l}0.004^{*} \\
(1.901)\end{array}$ & $\begin{array}{c}0.050^{* * *} \\
(4.614)\end{array}$ & $\begin{array}{c}0.331 * * * \\
(8.697)\end{array}$ & $\begin{array}{c}0.007 \\
(1.312)\end{array}$ & $\begin{array}{l}-0.210^{* *} \\
(-2.554)\end{array}$ & - & - & - & 0.94 \\
\hline$[10]$ & $\begin{array}{c}0.130 * * * \\
(5.037)\end{array}$ & $\begin{array}{l}0.117 * * \\
(2.560)\end{array}$ & $\begin{array}{l}0.004^{*} \\
(1.772)\end{array}$ & $\begin{array}{c}0.050 * * * \\
(4.777)\end{array}$ & $\begin{array}{c}0.334 * * * \\
(8.933)\end{array}$ & $\begin{array}{c}0.007 \\
(1.356)\end{array}$ & $\begin{array}{l}-0.211 * * \\
(-2.548)\end{array}$ & $\begin{array}{c}-0.013 \\
(-0.018)\end{array}$ & - & - & 0.94 \\
\hline$[11]$ & $\begin{array}{c}0.127^{* * *} \\
(5.004) \\
\end{array}$ & $\begin{array}{c}0.136 * * * \\
(3.438) \\
\end{array}$ & $\begin{array}{l}0.004^{*} \\
(1.662)\end{array}$ & $\begin{array}{c}0.050 * * * \\
(4.608)\end{array}$ & $\begin{array}{c}0.333 * * * \\
(8.562)\end{array}$ & $\begin{array}{c}0.007 \\
(1.368)\end{array}$ & - & - & $\begin{array}{c}-0.209^{* *} \\
(-2.384)\end{array}$ & $\begin{array}{c}-0.317 * * * \\
(-5.040)\end{array}$ & 0.94 \\
\hline \multicolumn{12}{|c|}{ Dependent variable: $N$ MARGIN (2342 obs.) } \\
\hline$\left[9^{\prime}\right]$ & $\begin{array}{c}0.232^{* * *} \\
(2.832)\end{array}$ & $\begin{array}{c}0.403 * * * \\
(3.614)\end{array}$ & $\begin{array}{c}-0.053^{* * *} \\
(-8.436)\end{array}$ & $\begin{array}{l}-0.100^{*} \\
(-1.695)\end{array}$ & $\begin{array}{c}0.256 \\
(0.884)\end{array}$ & $\begin{array}{c}0.010 \\
(1.366)\end{array}$ & $\begin{array}{c}-0.709^{* * *} \\
(-6.429)\end{array}$ & - & - & - & 0.91 \\
\hline [10’] & $\begin{array}{c}0.232 * * * \\
(2.841)\end{array}$ & $\begin{array}{c}0.457 * * * \\
(4.199)\end{array}$ & $\begin{array}{c}-0.053 * * * \\
(-8.349)\end{array}$ & $\begin{array}{l}-0.100^{*} \\
(-1.691)\end{array}$ & $\begin{array}{c}0.252 \\
(0.876)\end{array}$ & $\begin{array}{c}0.010 \\
(0.359)\end{array}$ & $\begin{array}{c}-0.737 * * * \\
(-5.870)\end{array}$ & $\begin{array}{c}-4.029 \\
(-0.868)\end{array}$ & - & - & 0.91 \\
\hline [11'] & $\begin{array}{c}0.232 * * * \\
(2.789)\end{array}$ & $\begin{array}{c}0.318 * * * \\
(3.723)\end{array}$ & $\begin{array}{c}-0.054 * * * \\
(-8.332)\end{array}$ & $\begin{array}{l}-0.102 * \\
(-1.744)\end{array}$ & $\begin{array}{c}0.259 \\
(0.909)\end{array}$ & $\begin{array}{c}0.011 \\
(0.438)\end{array}$ & - & - & $\begin{array}{c}-0.544 * * * \\
(-3.401)\end{array}$ & $\begin{array}{c}-0.558 \\
(-1.145)\end{array}$ & $0 ? 91$ \\
\hline
\end{tabular}

***, ** and * indicate significance respectively at the 1\%, 5\% and 10\% levels. $t$-statistics are corrected for heteroskedasticity following White's methodology.

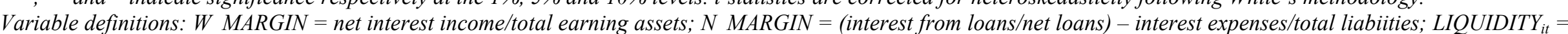
net loans/deposits; $C R 5_{j t}=$ five-bank asset concentration for country $j: R 3 M_{j t}=$ the three-month interbank rate for country $j ; L L P$ it $=$ loan loss provisions $/$ net loans for bank $i$

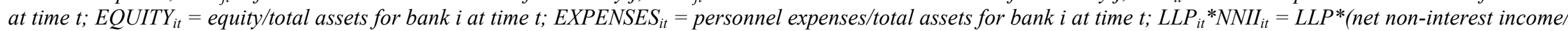
total net operating income) for bank $i$ at time $t ; L L P_{i t}{ }^{*} C O M_{i t}=L L P *\left(\right.$ net commission and fee income/ total net operating income) for bank $i$ at time $t ; L L P_{i t} * T R A D_{i t}=L L P *($ net trading incomel total net operating income) for bank $i$ at time $t: L L P P_{i t}^{*} C O M S H A_{i t}=L L P *(n e t$ commission and fee income/ net non-interest income). All the variables are expressed in \%. Therefore, the interaction variables are divided by 100 to obtain coefficients that can be directly compared to the coefficient of LLP. 
Table 5. Two way fixed effect regression (LSDV): impact of interaction variables (product diversification*credit risk) on risk premium for European banks (1996-2002)

$\operatorname{SPREAD}_{\mathrm{it}}=\beta_{1 \mathrm{i}}+\beta_{2}$ VR3M $_{\mathrm{it}}+\beta_{3} \operatorname{LLP}_{\mathrm{it}}+\beta_{4}$ EQUITY $_{\mathrm{it}}+\beta_{5}$ EXPENSES $_{\mathrm{it}}+\beta_{6} \mathrm{CR}_{\mathrm{it}}+\beta_{11}\left(\operatorname{LLP}_{\mathrm{it}} \times \mathrm{NNII}_{\mathrm{it}}\right) / 100+\varepsilon_{\mathrm{it}}$

$\operatorname{SPREAD}_{\mathrm{it}}=\beta_{1 \mathrm{i}}+\beta_{2} \mathrm{VR}_{\mathrm{j}}+\beta_{3} \operatorname{LLP}_{\mathrm{it}}+\beta_{4}$ EQUITY $_{\mathrm{it}}+\beta_{5}$ EXPENSES $_{\mathrm{it}}+\beta_{6} \mathrm{CR}_{\mathrm{jt}}+\beta_{11}\left(\operatorname{LLP}_{\mathrm{it}} \times \mathrm{NNII}_{\mathrm{it}}\right) / 100+\beta_{12}\left(\operatorname{LLP}_{\mathrm{it}} \times \operatorname{COMSHA}_{\mathrm{it}}\right) / 100+\varepsilon_{\mathrm{it}}$ $\operatorname{SPREAD}_{\mathrm{it}}=\beta_{1 \mathrm{i}}+\beta_{2} \mathrm{VR} \mathrm{M}_{\mathrm{jt}}+\beta_{3} \operatorname{LLP}_{\mathrm{it}}+\beta_{4}$ EQUITY $_{\mathrm{it}}+\beta_{5}$ EXPENSES $_{\mathrm{it}}+\beta_{6} \mathrm{CR}_{\mathrm{jt}}+\beta_{13}\left(\operatorname{LLP}_{\mathrm{it}} \times \mathrm{COM}_{\mathrm{it}}\right) / 100+\beta_{14}\left(\operatorname{LLP}_{\mathrm{it}} \times \mathrm{TRAD}_{\mathrm{it}}\right) / 100+\varepsilon_{\mathrm{it}}$

\begin{tabular}{|c|c|c|c|c|c|c|c|c|c|c|}
\hline & $\begin{array}{l}\text { VR3M } \\
(+)\end{array}$ & $\begin{array}{c}\text { LLP } \\
(+)\end{array}$ & $\begin{array}{c}\text { EQUITY } \\
(+)\end{array}$ & $\begin{array}{c}\text { EXPENSES } \\
(+/-)\end{array}$ & $\begin{array}{c}\text { CR5 } \\
(+)\end{array}$ & $\begin{array}{c}\text { NNII*LLP/100 } \\
(-)\end{array}$ & $\begin{array}{c}\text { LLP*COMSHA } / 100 \\
(-)\end{array}$ & $\underset{(-)}{\mathrm{LLP} * \mathrm{COM}^{*} / 100}$ & $\begin{array}{c}\text { LLP } * \text { TRAD } / 100 \\
(-)\end{array}$ & R2 \\
\hline \multicolumn{11}{|c|}{ Dependent variable: $W$ SPREAD (4048 obs.) } \\
\hline$[12]$ & $\begin{array}{c}0.460^{* * *} \\
(3.407)\end{array}$ & $\begin{array}{c}0.914^{* * *} \\
(4.796)\end{array}$ & $\begin{array}{r}-0.021^{* *} \\
(-2.070)\end{array}$ & $\begin{array}{c}0.211^{* * *} \\
(3.653)\end{array}$ & $\begin{array}{c}0.002 \\
(0.736)\end{array}$ & $\begin{array}{l}-1.111^{* * *} \\
(-3.463)\end{array}$ & - & - & - & 0.57 \\
\hline$[13]$ & $\begin{array}{c}0.459 * * * \\
(3.392)\end{array}$ & $\begin{array}{c}0.934 * * * \\
(4.598)\end{array}$ & $\begin{array}{r}-0.022^{* *} \\
(-2.066)\end{array}$ & $\begin{array}{l}0.211^{* * *} \\
(3.646)\end{array}$ & $\begin{array}{c}0.002 \\
(0.785)\end{array}$ & $\begin{array}{c}-1.116^{* * * *} \\
(-3.435)\end{array}$ & $\begin{array}{l}-2.156 \\
(-0.227)\end{array}$ & - & - & 0.57 \\
\hline$[14]$ & $\begin{array}{c}0.378 * * * \\
(2.823)\end{array}$ & $\begin{array}{c}0.620 * * * \\
(8.626)\end{array}$ & $\begin{array}{c}-0.015 \\
(-1.409)\end{array}$ & $\begin{array}{l}0.181 * * \\
(2.624)\end{array}$ & $\begin{array}{c}0.003 \\
(1.451)\end{array}$ & - & - & $\begin{array}{c}-2.166^{* * *} \\
(-8.647)\end{array}$ & $\begin{array}{c}-0.121 \\
(-0.248)\end{array}$ & 0.57 \\
\hline \multicolumn{11}{|c|}{ Dependent variable: $N$ SPREAD (2342 obs.) } \\
\hline [12’] & $\begin{array}{c}1.346^{* * * *} \\
(6.768)\end{array}$ & $\begin{array}{c}0.636^{* * *} \\
(6.555)\end{array}$ & $\begin{array}{c}0.089^{* * * *} \\
(8.294)\end{array}$ & $\begin{array}{c}0.241^{* *} \\
(2.586)\end{array}$ & $\begin{array}{l}0.056^{* * *} \\
(15.801)\end{array}$ & $\begin{array}{l}-0.644^{*} \\
(-1.952)\end{array}$ & - & - & - & 0.22 \\
\hline [13'] & $\begin{array}{c}1.349 * * * \\
(6.767)\end{array}$ & $\begin{array}{c}0.692 * * * \\
(6.891)\end{array}$ & $\begin{array}{c}0.088^{* * * *} \\
(8.830)\end{array}$ & $\begin{array}{c}0.243 * * \\
(2.604)\end{array}$ & $\begin{array}{l}0.056^{* * *} \\
(15.814)\end{array}$ & $\begin{array}{c}-0.599 * * * \\
(-2.827)\end{array}$ & $\begin{array}{c}-11.166^{*} \\
(-1.746)\end{array}$ & - & - & 0.22 \\
\hline [14'] & $\begin{array}{c}1.324 * * * \\
(6.509)\end{array}$ & $\begin{array}{c}0.620 * * * \\
(8.702)\end{array}$ & $\begin{array}{c}0.095^{* * * *} \\
(9.010)\end{array}$ & $\begin{array}{l}0.202 * * \\
(2.261)\end{array}$ & $\begin{array}{l}0.057 * * * \\
(15.943)\end{array}$ & - & - & $\begin{array}{c}-1.007 * * * \\
(-2.814)\end{array}$ & $\begin{array}{c}-0.004 \\
(-0.009)\end{array}$ & 0.22 \\
\hline
\end{tabular}

***,** and * indicate significance respectively at the 1\%, 5\% and 10\% levels. $t$-statistics are corrected for heteroskedasticity following White's methodology.

Variable definitions: $W$ SPREAD = the ratio of net interest income to total earning assets - the ten-year government bond rate; $N$ SPREAD = lending rate determined as the ratio of interest from loans to net loans - the ten-year government bond rate; $C R 5_{j t}=$ five-bank asset concentration for country $j$; VR $3 M_{j t}=v_{\text {volatility }}$ of the three-month

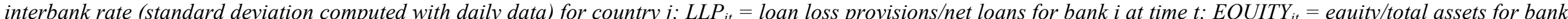
$i$ at time $t$; EXPENSES $S_{i t}=$ personnel expenses/total assets for bank $i$ at time $t ; L L P_{i t}{ }^{*} N N I I_{i t}=L L P^{*}$ (net non-interest income/ total net operating income) for bank $i$ at time $t$; $L L P_{i t} * C O M_{i t}=L L P *\left(\right.$ net commission and fee income/ total net operating income) for bank $i$ at time $t$; LLP $P_{i t}^{*} T R A D_{i t}=L L P *($ net trading income/ total net operating income) for bank $i$ at time $t ; L L P_{i t}^{*} C O M S H A_{i t}=L L P *(n e t$ commission and fee incomel net non-interest income). All the variables are expressed in \%. Therefore, the interaction variables are divided by 100 to obtain coefficients that can be directly compared to the coefficient of LLP. 


\section{References}

Angbazo, L., 1997. Commercial bank interest margins, default risk, interest-rate risk, and offbalance sheet banking. Journal of Banking and Finance 21(1), 55-87.

Baele, L., De Jonghe O., Vander Vennet, R., 2006. Does the stock market value bank diversification? Journal of Banking and Finance, forthcoming.

Boyd, J., Chang, C., Smith, D., 1998. Moral hazard under commercial and universal banking. Journal of Money, Credit and Banking 30(3).

Boyd, J., Graham, S., 1986. Risk, regulation, and bank holding company expansion. Federal Reserve Bank of Mineapolis, Quaterly Review, spring.

Boyd, J., Graham, G., Hewitt, R., 1993. Bank holding company mergers with nonbank financial firms. Journal of Banking and Finance 17, 43-63.

Boyd, J., Hanweck, G., Pithyachariyakul, P., 1980. Bank holding company diversification. Federal Reserve Bank of Chicago, Proceedings from a conference on Bank Structure and Competition, May, 105-120.

Carbó, S., Rodriguez, F., 2007. The determinants of bank margins in European banking. Journal of Banking and Finance 31, 2043-2063.

DeYoung, R., Roland, K., 2001. Product mix and earnings volatility at commercial banks: Evidence from a degree of total leverage model. Journal of Financial Intermediation 10, 5484.

Dingell, J., 2002. Letter to FRB and OCC re : "pay to play" practices, Jul 11. Available from www.house.gov/commerce_democrats/press/107ltr179.htm.

Drakos, K., 2003. Assessing the success of reform in transition banking 10 years later: An interest margins analysis. Journal of Policy Modeling 25(3), 309-317.

European Central Bank, 2000. EU banks' income structure. Banking Supervision Committee, April.

Hausman, J., 1978. Specification Tests in Econometrics. Econometrica 46, 1251-1271.

Ho, T., Saunders, A., 1981. The determinants of bank interest margins : Theory and empirical evidence. Journal of Financial and Quantitative Analysis 16(4), 581-600.

John, K., John, T.A., Saunders A., 1994. Universal banking and firm risk-taking. Journal of Banking and Finance 18(2), 307-323.

Klein, M., 1971. A theory of the banking firm. Journal of Money, Credit and Banking 3(2), 205-218. 
Kwan, S., 1998. Securities activities by commercial banking firms' section 20 subsidiaries: risk, return and diversification benefits. Economic Research, Federal Reserve Bank of San Francisco.

Lepetit, L., Nys, E., Rous, P., Tarazi, A., 2007. Bank income structure and risk: An empirical analysis of European banks. Journal of Banking and Finance, forthcoming.

Maudos, J., De Guevara, J.F., 2004. Factors explaining the interest margin in the banking sectors of the European Union. Journal of Banking and Finance 28, 2259-2281.

Merton R.C., 1977. On the pricing of contingent claims and the Modigliani-Miller theorem. Journal of Financial Economics (5), 241-249.

Monti, M, 1972. Deposit, credit and interest rate determination under alternative bank objective functions. In: Karl Shell and Giorgio P. Szego, eds., Mathematical methods in investment and finance, North-Holland, Amsterdam, 430-454.

Petersen, M.A., Rajan, R.G., 1995. The effect of credit market competition on lending relationships. Quarterly Journal of Economics 110, 406-443.

Puri, M., 1996. Conflicts of interest, intermediation, and the pricing of underwritten securities. Mimeo, Graduate School of Business, Stanford University, Mars.

Rajan, R., 1991. Conflict of interest and the separation of commercial and investment banking. Working Paper, University of Chicago.

Saunders, A., Schumacher, L., 2000. The determinants of bank interest margins: An international study. Journal of International Money and Finance 19(6), 813-832.

Smith, R., Staikouras, C., Wood, G., 2003. Non-interest income and total income stability.Working Paper $n^{\circ} 198$ - Bank of England.

Stiroh, K., 2004. Diversification in banking: Is non-interest income the answer? Journal of Money, Credit and Banking 36(5), 853-882.

Stiroh, K., Rumble, A., 2006. The dark side of diversification: The case of US financial holding companies. Journal of Banking and Finance 30(8), 2131-2161.

Wong, K.P., 1997. On the determinants of bank interest margins under credit and interest rate risks. Journal of Banking and Finance 21(2), 251-271. 


\section{Appendix}

Table A1. Distribution of banks by country

\begin{tabular}{lc}
\hline \hline & Numbers of banks \\
\hline Austria & 3 \\
Belgium & 17 \\
Denmark & 42 \\
France & 149 \\
Italy & 152 \\
Netherlands & 24 \\
Norway & 15 \\
Portugal & 16 \\
Spain & 15 \\
Sweden & 6 \\
Switzerland & 106 \\
United Kingdom & 57 \\
\hline \hline
\end{tabular}

